\title{
Phosphatidylcholine induces apoptosis of 3T3-L1 adipocytes
}

\author{
Hailan $\mathrm{Li}^{1 \dagger}$, Jong-Hyuk Lee ${ }^{2 \dagger}$, Su Yeon Kim', Hye-Young Yun ${ }^{1}$, Kwang Jin Baek', Nyoun Soo Kwon', Yoosik Yoon ${ }^{3}$, \\ Ji Hoon Jeong ${ }^{2}$ and Dong-Seok Kim ${ }^{1 *}$
}

\begin{abstract}
Background: Phosphatidylcholine (PPC) formulation is used for lipolytic injection, even though its mechanism of action is not well understood.

Methods: The viability of 3T3-L1 pre-adipocytes and differentiated 3T3-L1 cells was measured after treatment of PPC alone, its vehicle sodium deoxycholate (SD), and a PPC formulation. Western blot analysis was performed to examine PPC-induced signaling pathways.

Results: PPC, SD, and PPC formulation significantly decreased 3T3-L1 cell viability in a concentration-dependent manner. PPC alone was not cytotoxic to CCD-25Sk human fibroblasts at concentrations $<1 \mathrm{mg} / \mathrm{ml}$, whereas SD and PPC formulation were cytotoxic. Western blot analysis demonstrated that PPC alone led to the phosphorylation of the stress signaling proteins, such as p38 mitogen-activated protein kinase and c-Jun N-terminal kinase, and activated caspase-9, $-8,-3$ as well as cleavage of poly(ADP-ribose) polymerase. However, SD did not activate the apoptotic pathways. Instead, SD and PPC formulation induced cell membrane lysis, which may lead to necrosis of cells.
\end{abstract}

Conclusions: PPC results in apoptosis of 3T3-L1 cells.

Keywords: adipocytes, apoptosis, caspases, mesotherapy, PPC

\section{Background}

Mesotherapy is a new technique of injecting drugs into the mesoderm for the treatment of local conditions [1]. This method allows the use of increased concentration of drugs and can produce greater treatment effects. Mesotherapy has been used for many infirmities, such as fat emboli, chronic pain, hyperlipidemia, and liver problems [2]. Phosphatidycholine (PPC) formulation has been widely-used to dissolve local fat deposits as a safe nonsurgical alternative to liposuction [3]. Many clinical studies have reported that the subcutaneous injection of PPC formulation reduces fat [3-5]. Although the biochemical mechanisms are very poorly studied, it has been suggested that no enzymatic lipolytic pathway is involved [6]. Thus, it is thought that the PPC formulation

\footnotetext{
* Correspondence: ds_kim@cau.ac.kr

† Contributed equally

'Departments of Biochemistry, Chung-Ang University College of Medicine,

221 Heukseok-dong, Dongjak-gu, Seoul 156-756, Republic of Korea

Full list of author information is available at the end of the article
}

dissolves local fat deposits in a nonspecific manner [7]. PPC formulation has not been approved by the Food and Drug Administration (FDA) for use in lipodissolution.

PPC is a lecithin-derived phospholipid [4], which is widely-distributed in human cell membranes [8]. The Lands cycle and the Kennedy pathway are two pathways of PPC synthesis [9], and they take place in the endoplasmic reticulum [10]. Increased PPC in cell membranes can accelerate lipolysis by improving sensitivity to insulin $[5,11]$. In addition, PPC is the major phospholipid in pulmonary surfactant [12]. On the other hand, PPC induces apoptosis of hepatic cancer cells [13]. Moreover, the size of lipomas is reduced after intralesional injection of PPC [14].

Obesity is one of the main health problems in much of the Western world, as a consequence of the induction of various metabolic derangements including dyslipidemia, hypertension, glucose intolerance, and hepatic steatosis [15]. Obesity is identified by increased number and size of adipocytes [16]. Adipocytes, which store excess
Ciomed Central

(C) 2011 Li et al; licensee BioMed Central Ltd. This is an Open Access article distributed under the terms of the Creative Commons Attribution License (http://creativecommons.org/licenses/by/2.0), which permits unrestricted use, distribution, and reproduction in any medium, provided the original work is properly cited. 
energy, release paracrine factors that induce growth and differentiation of neighboring pre-adipocytes [17]. Therefore, both suppression of pre-adipocyte differentiation and decrease in cell viability of pre-adipocytes and adipocytes are possible ways to treat obesity. To date, many studies have focused on the inhibition of adipogenesis. However, the notable ability of adipocytes to resist apoptosis is poorly understood [18].

Cell death, including apoptosis and necrosis, are followed by the cleavage of proteins and DNA [19]. These two pathways of cell death are associated with different patterns of nuclear protein cleavage [20]. For example, poly(ADP-ribose) polymerase (PARP) cleavage generates an $85 \mathrm{kD}$ fragment during apoptosis but generates a 50 $\mathrm{kD}$ fragment in necrotic cell death [21]. Caspase-3 is an apoptotic signal transducer in 3T3-L1 pre-adipocytes [22].

In the present study, PPC formulations containing PPC and sodium deoxycholate (SD) were used. SD is a secondary bile salt and is used as a laboratory detergent to dissolve PPC [7]. Physiologically, however, SD, not PPC, could be the major active component for fat lysis $[7,23]$. To address this speculation, the present study assessed the effects of PPC alone, PPC formulation, and SD on 3T3-L1 pre-adipocytes and differentiated 3T3-L1 adipocytes. Until now, the actions of PPC and SD could not be directly compared, because PPC needs to be emulsified with SD. However, we could apply PPC alone using bovine serum albumin (BSA) as a carrier.

The specific aim of this study was to investigate the mechanism of cell death induced by PPC and/or SD in 3T3-L1 pre-adipocytes. Furthermore, our study focused on the apoptotic effect of PPC on 3T3-L1 preadipocytes.

\section{Materials and methods Materials}

L- $\alpha$-phosphatidylcholine from soybean (P7443, $\geq 99 \%$ ), fatty acid-free BSA, insulin, dexamethasone, 3-isobutyl1-methylxanthine, and 3-(4, 5-dimethylthiazol-2-yl)-2, 5diphenyltetrazolium bromide (MTT) were obtained from Sigma-Aldrich (St. Louis, MO, USA). PPC was added to cells as a complex with $0.4 \%$ BSA. Antibodies against phospho-p38 mitogen-activated protein kinase (MAPK) (Thr180/Tyr182) (CST-9211), phospho-c-JunN-terminal kinase (JNK) (Thr183/Tyr185) (CST-9251), and cleaved caspase-3 (CST-9661) were obtained from Cell Signaling Technology (Danvers, MA, USA). Antibodies against Bax (sc-526), Bcl-2 (sc-7382), caspase-9 (sc8355), caspase-8 (sc-7890), PARP (sc-7150), and actin (sc-1616) were purchased from Santa Cruz Biotechnology (Santa Cruz, CA, USA). SD was obtained from New Zealand Pharmaceuticals (Palmerston, New Zealand) and a type of PPC formulation, Lipobean ${ }^{\circledR}(50 \mathrm{mg} / \mathrm{ml}$, containing $2.4 \% \mathrm{SD}$ ) was kindly supplied by AmiPharm (Seoul, Korea).

\section{Cell cultures}

3T3-L1 pre-adipocytes were obtained from ATCC (Rockville, MD, USA). The cells were grown in Dulbecco's Modified Eagle's Medium (DMEM) supplemented with $10 \%$ bovine calf serum (BCS; Invitrogen, Carlsbad, CA, USA), $50 \mu \mathrm{g} / \mathrm{ml}$ of streptomycin, and $50 \mu \mathrm{g} / \mathrm{ml}$ of penicillin at $37^{\circ} \mathrm{C}$ in $5 \% \mathrm{CO}_{2}$. After cells were reached confluence, designated day 0 , the cells were maintained with differentiation-induction medium containing 0.5 mM 3-isobutyl-1-methylxanthine, $0.25 \mu \mathrm{M}$ dexamethasone, $1 \mu \mathrm{g} / \mathrm{ml}$ insulin (MDI) and in DMEM with $10 \%$ BCS for 4 days. Next, the culture medium was changed to differentiation maintenance medium containing $1 \mu \mathrm{g} /$ $\mathrm{ml}$ insulin in DMEM with 10\% BCS for 2 days.

\section{MTT assay for cell viability}

Cells $\left(1 \times 10^{4}\right.$ cells/well), seeded into 12 -well plates for $24 \mathrm{~h}$, were incubated with various concentrations of PPC, SD, and Lipobean ${ }^{\circledR}(0-1 \mathrm{mg} / \mathrm{ml})$ in DMEM containing $10 \%$ fetal bovine serum (FBS) at $37^{\circ} \mathrm{C}$ in $5 \% \mathrm{CO}_{2}$ for $24 \mathrm{~h}$. After adding $100 \mu \mathrm{l} /$ well of MTT solution (5 $\mathrm{mg} / \mathrm{ml}$ ), the plates were incubated for another $4 \mathrm{~h}$. Supernatants were then removed and the formazan crystals were solubilized in $1 \mathrm{ml}$ of dimethylsulfoxide. Optical density was determined at $540 \mathrm{~nm}$ using a VERSAMax ELISA reader (Molecular Devices, Sunnyvale, CA, USA).

\section{Cell cycle analysis}

Cells were trypsinized, adjusted to a density of $5 \times 10^{5}$ $1 \times 10^{6}$ cells/tube, washed with ice-cold phosphate-buffered saline (PBS), and re-suspended in $2 \mathrm{ml}$ of ethanol. After incubation at $4^{\circ} \mathrm{C}$ for $1 \mathrm{~h}$, the ethanol was removed and $100 \mu \mathrm{l}$ of ribonuclease solution $(10 \mathrm{mg} / \mathrm{ml})$ was added to each test tube. The tubes were then reincubated at room temperature for $30 \mathrm{~min}$, and $500 \mu \mathrm{l}$ of analysis solution (37 mM EDTA and $0.1 \%$ Triton X100 in PBS) and $100 \mu \mathrm{l}$ of propidium iodide solution $(400 \mu \mathrm{g} / \mathrm{ml})$ were then added. Samples were stored in the dark at $4{ }^{\circ} \mathrm{C}$ and analyzed using a FACSCalibur flow cytometer (Becton Dickinson, San Jose, CA, USA).

\section{Western blotting}

Cells were grown in $100 \mathrm{~mm}$-diameter culture dishes, serum-starved for $24 \mathrm{~h}$, and treated with PPC, SD, and Lipobean ${ }^{\circledR}$ at the indicated times. Cell lysates were prepared in M-PER mammalian protein reagent (Pierce, Rockford, IL, USA) containing a complete protease inhibitor mixture (Roche, Mannheim, Germany). Samples were separated by $12 \%$ sodium dodecyl sulfate-polyacrylamide gel electrophoresis (SDS-PAGE) and the resolved 
proteins were transferred to polyvinylidene fluoride (PVDF) membranes, which were blocked with 5\% dried milk in PBS containing 0.5\% Tween 20. The blots were incubated with the appropriate primary antibodies at a dilution of 1:1000. Membrane-bound primary antibodies were detected using secondary antibodies conjugated with horseradish peroxidase and chemiluminescent substrate (Pierce). The images of the blotted membranes were obtained using a LAS-1000 lumino-image analyzer (Fuji Film, Tokyo, Japan).

\section{Statistical analyses}

Differences between groups were assessed with an analysis of variance, followed by the Student's $t$-test. $P$ values $<0.01$ were considered significant.

\section{Results}

Effects of PPC, SD, and Lipobean ${ }^{\circledR}$ on 3T3-L1 preadipocyte viability

To examine cytotoxicity, 3T3-L1 pre-adipocytes were treated with PPC, SD, and Lipobean ${ }^{\circledR}$ at $0-1 \mathrm{mg} / \mathrm{ml}$ for $24 \mathrm{~h}$. Cell viabilities were measured by MTT assay (Figure 1A). PPC and Lipobean ${ }^{\circledR}$ at $0.1 \mathrm{mg} / \mathrm{ml}$ already induced 3T3-L1 cell death in about $50 \%$ of the tested populations, whereas SD at $0.1 \mathrm{mg} / \mathrm{ml}$ did not show cytotoxic activity. The morphology of 3T3-L1 cells after PPC, $\mathrm{SD}$, and Lipobean ${ }^{\circledR}$ treatment of $0.1 \mathrm{mg} / \mathrm{ml}$ is shown in Figure 1B. After Lipobean ${ }^{\circledR}$ treatment, cell membrane disturbance was evident because of cell death. However, PPC-induced cell death produced different morphological changes. We next tested the viability of normal
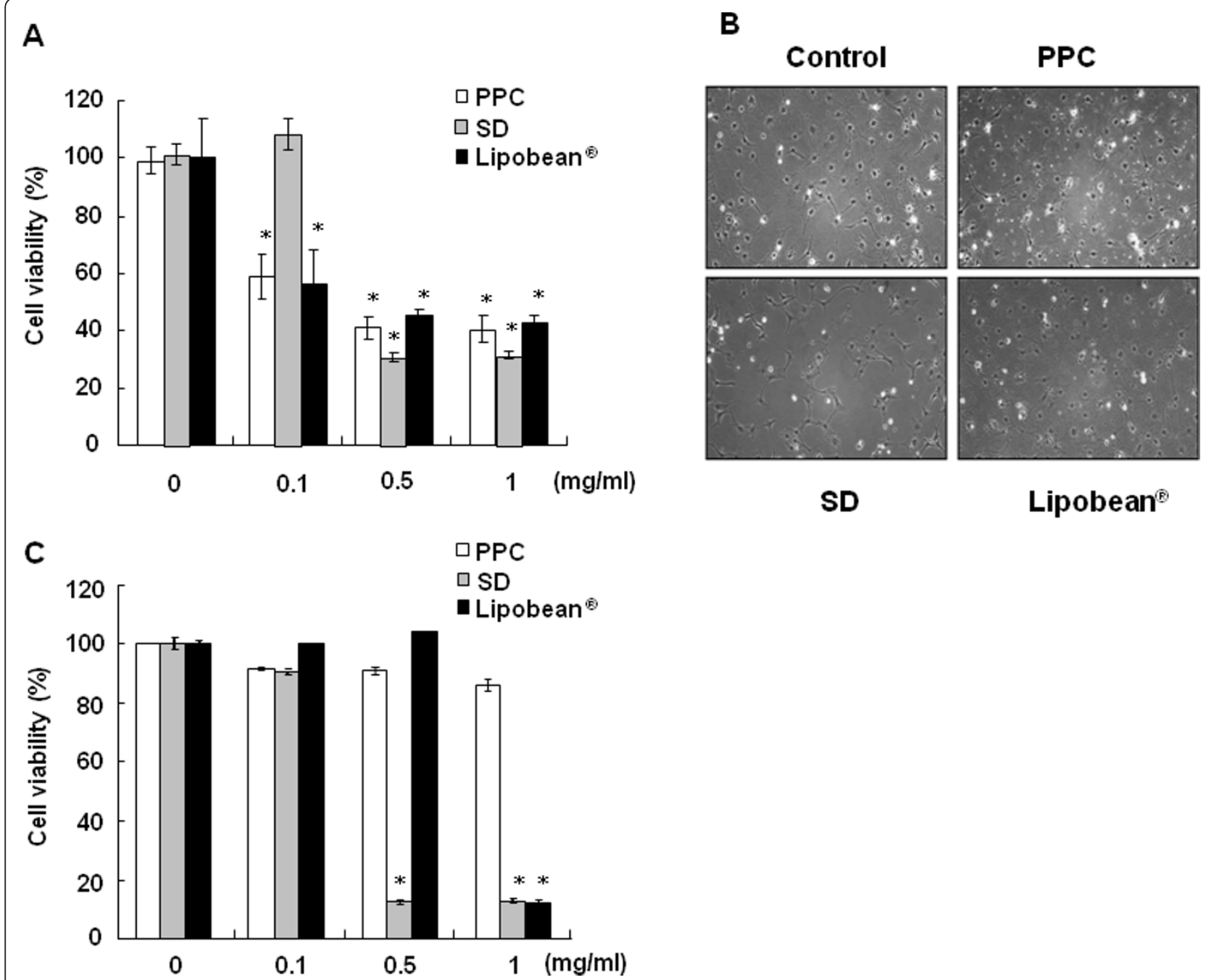

SD

Lipobean

Figure 1 Effects of PPC on cell viabilities. (A) 3TC-L1 cells were treated with PPC, SD, Lipobean ${ }^{\circledR}$ at 0-1 mg/ml. (B) Morphology of 3T3-L1 cells after $0.1 \mathrm{mg} / \mathrm{ml}$ of PPC, SD, Lipobean ${ }^{\circledR}$ treatment. Phase contrast photographs were taken using a digital video camera. (C) CCD-25Sk human fibroblasts were treated with PPC, SD, Lipobean ${ }^{\circledR}$ at 0-1 mg/ml. After $24 \mathrm{~h}$, cell viability was measured by MTT assay. The data represent the mean \pm standard deviation (S.D.) of triplicate assays expressed as percentages of the control. Each experiment was repeated independently at least twice, and the representative results are shown. ${ }^{*} P<0.01$ compared to the untreated control. 
human fibroblast cell line, CCD-25Sk, after treatment with PPC, SD, and Lipobean ${ }^{\circledR}$. PPC had little influence on CCD-25Sk cell viability at the concentrations tested, whereas SD and Lipobean ${ }^{\circledR}$ significantly decreased cell viability by about $80 \%$ at $1 \mathrm{mg} / \mathrm{ml}$ (Figure $1 \mathrm{C}$ ).

\section{Recovery effects of media change on 3T3-L1 and CCD- 25Sk cell death}

To examine the recovery from PPC, SD, or Lipobean ${ }^{\circledR}$ induced cell death, 3T3-L1 and CCD-25Sk cells were supplied with fresh medium for $72 \mathrm{~h}$ and $96 \mathrm{~h}$, after which the cells were treated with PPC, SD, and Lipobean ${ }^{\mathbb{B}}$ at 0.1 and $1 \mathrm{mg} / \mathrm{ml}$. Cell viability was then measured by the MTT assay. PPC-induced 3T3-L1 cell death was recovered in a minimal fashion, whereas Lipobean ${ }^{\circledR}$-induced cell death was dramatically abrogated (Figure 2A). On the other hand, SD- or Lipobean ${ }^{\circledR}$-induced CCD-25Sk cell death was not recovered by a change of fresh media, whereas the viability of PPC-treated CCD-25Sk cells was increased significantly after medium change (Figure 2B).

\section{PPC induces stress-regulated signaling pathway and} apoptotic pathway activation

Next, it was investigated whether p38 MAPK or JNK could be activated by PPC, SD, and Lipobean ${ }^{\circledR}$ treatment. PPC or SD $(0.1 \mathrm{mg} / \mathrm{ml})$ resulted in the activation of p38 MAPK and JNK, while Lipobean ${ }^{\circledR}$ did not (Figure
3A). We further examined changes of the apoptotic pathways induced by PPC, SD, and Lipobean ${ }^{\circledR}$ (Figure 3B). PPC clearly up-regulated Bax expression in 3T3-L1 cells, but had little influence on $\mathrm{Bcl}-2$ expression. Thus, PPC treatment substantially increased the Bax/Bcl-2 ratio. Caspases become active when they are cleaved into processed fragments. In this experiment, we used antibodies directed against the precursor forms of caspase- 9 and caspase-8. As shown in Figure 3B, PPC cleaved and activated caspase- 9 and caspase- 8 . An antibody directed against the cleaved form of caspase- 3 was also used, and the active form of caspase- 3 increased upon PPC treatment. Caspase- 3 is believed to be the most efficient PARP-cleaving caspase. Accordingly, we found that the full-length PARP was cleaved after PCC treatment. However, SD and Lipobean ${ }^{\circledR}$ did not show these apoptotic changes.

\section{Effects of PPC, SD, and Lipobean ${ }^{\circledR}$ on differentiated 3T3- L1 cells}

3T3-L1 pre-adipocytes were differentiated with MDI medium for 6 days. Thereafter, differentiated 3T3-L1 cell viabilities were also tested after the treatment of PPC, SD, and Lipobean ${ }^{\circledR}$ at $0-1 \mathrm{mg} / \mathrm{ml}$ for $24 \mathrm{~h}$ (Figure 4A). The results concerning differentiated 3T3-L1 cells showed almost same tendency in 3T3-L1 pre-adipocytes. Furthermore, cell cycle changes were analyzed by flow cytometry (Figure 4B). Consistent with the cell viability
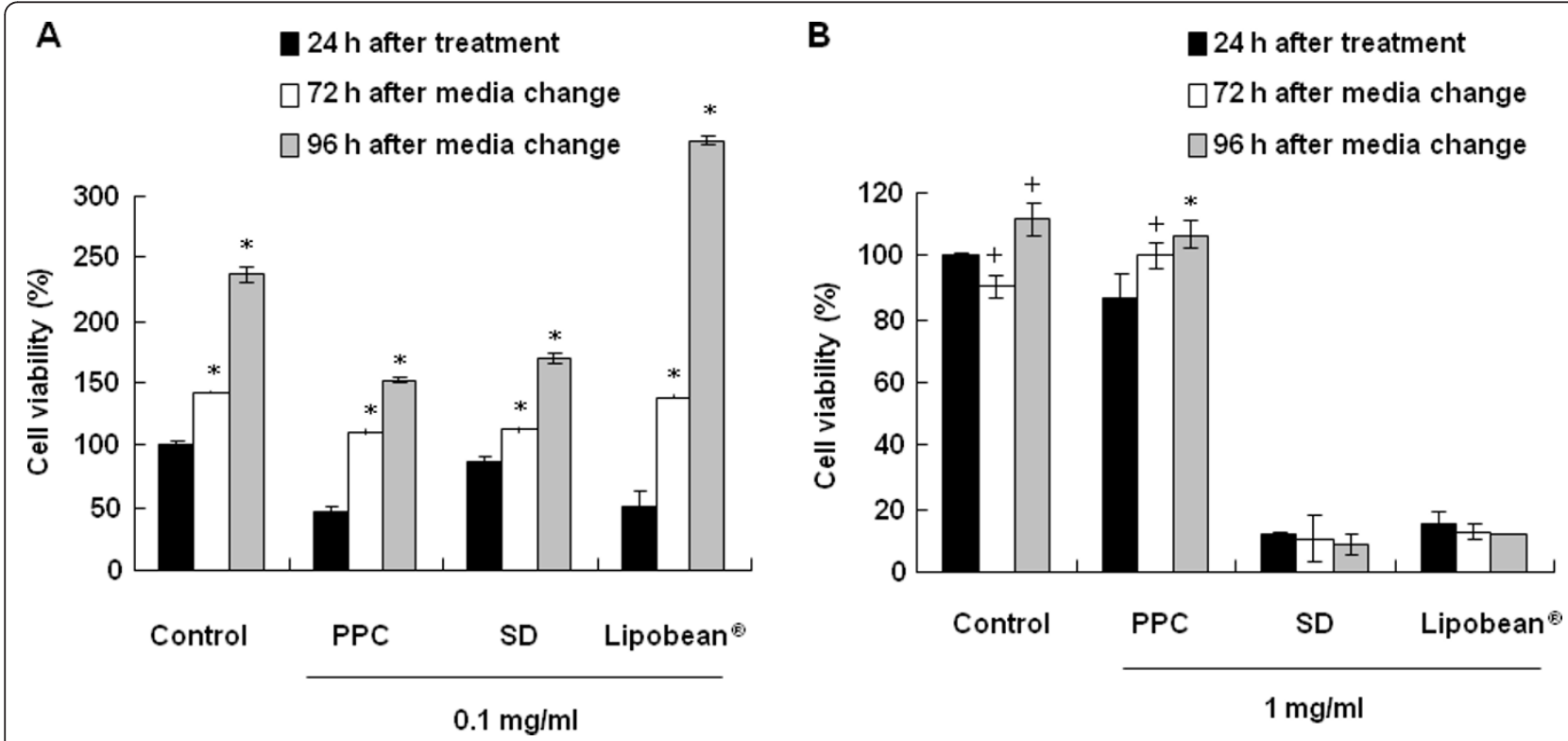

Figure 2 Effects of media change on cell recovery. (A) 3TC-L1 cells were treated with PPC, SD, Lipobean ${ }^{\circledR}$ at 0.1 mg/ml. (B) CCD-25Sk cells were treated with PPC, SD, Lipobean ${ }^{\circledR}$ at $1 \mathrm{mg} / \mathrm{ml}$. After $24 \mathrm{~h}$, the media was removed and then was changed with fresh media. The cell viability was measured by MTT assay after 72-96 h incubation in fresh media. The data represent the mean \pm S.D. of triplicate assays expressed as percentages of the control. Each experiment was repeated independently at least twice, and the representative results are shown. $+P<0.05$, * $P<0.01$ compared to $24 \mathrm{~h}$ treated each group. 


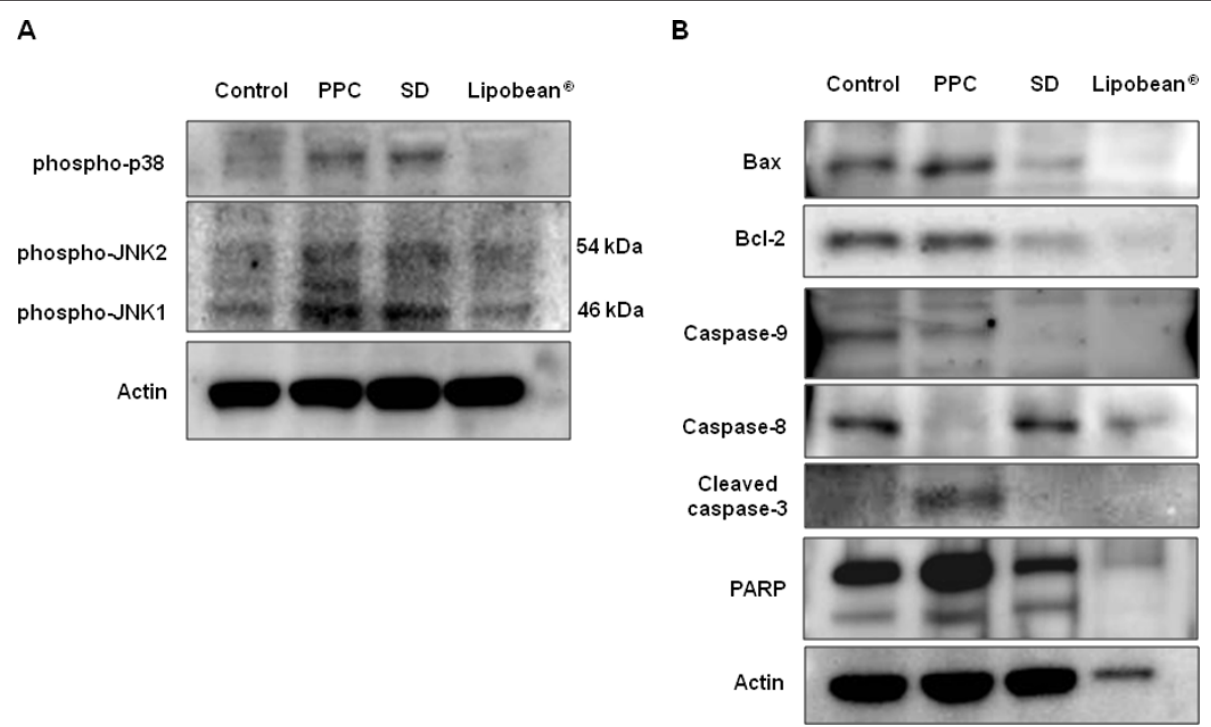

Figure 3 Effects of PPC, SD, and Lipobean ${ }^{\circledR}$ on apoptotic pathways. (A) After serum starvation, 3T3-L1 pre-adipocytes were treated with PPC, SD, and Lipobean ${ }^{\circledR}$ at $0.1 \mathrm{mg} / \mathrm{ml}$ for $4 \mathrm{~h}$. Whole cell lysates were then subjected to Western blot analysis with antibodies against phosphospecific p38 MAPK and phospho-specific JNK. (B) After serum starvation, 3T3-L1 pre-adipocytes were treated with PPC, SD, and Lipobean ${ }^{\circledR}$ at 1 $\mathrm{mg} / \mathrm{ml}$ for $24 \mathrm{~h}$. Whole cell lysates were then subjected to Western blot analysis with antibodies against Bax, Bcl-2, caspase-9, caspase-8, cleaved caspase-3, and PARP. Equal protein loadings were confirmed using anti-actin antibody.

A
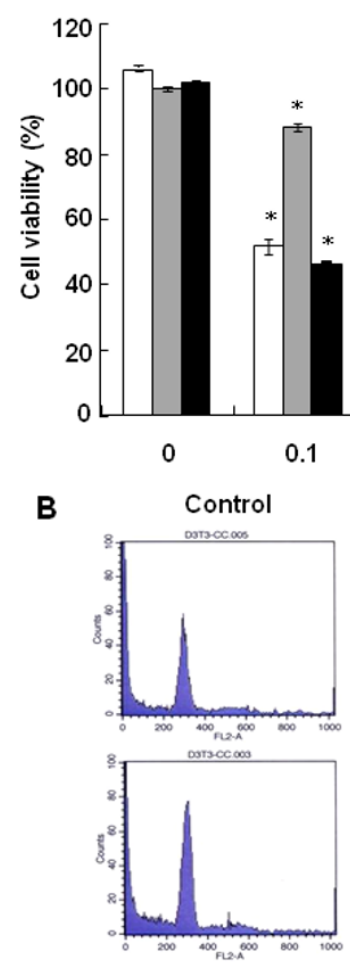

SD
C

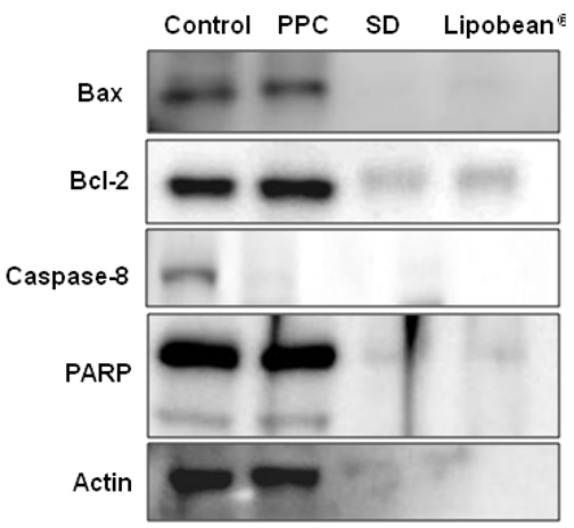

Figure 4 Effects of PPC, SD, and Lipobean ${ }^{\circledR}$ on differentiated 3T3-L1 cells. 3T3-L1 pre-adipocytes were differentiated for 6 days with MDI media. (A) Differentiated 3T3-L1 cells were treated with PPC, SD, and Lipobean ${ }^{\circledR}$ at 0-1 mg/ml. After $24 \mathrm{~h}$, cell viability was measured by the MTT assay. The data represent the mean \pm S.D. of triplicate assays expressed as percentages of the control. ${ }^{*} P<0.01$ compared to the untreated control (B) Differentiated 3T3-L1 cells were treated with PPC, SD, and Lipobean ${ }^{\circledR}$ at $0.1 \mathrm{mg} / \mathrm{ml}$ for $24 \mathrm{~h}$. Cell cycle analysis of cells was performed by a flow cytometer. (C) Differentiated 3T3-L1 cells were treated with PPC, SD, and Lipobean ${ }^{\circledR}$ at $1 \mathrm{mg} / \mathrm{ml}$ for $24 \mathrm{~h}$. Whole cell lysates were then subjected to Western blot anaysis with antibodies against Bax, BCl-2, caspase-8, and PARP. Equal protein loadings were confirmed using anti-actin antibody. 
results, cell cycle disruption was observed when differentiated 3T3-L1 cells were treated with PPC and Lipobean ${ }^{\circledR}$ at $0.1 \mathrm{mg} / \mathrm{ml}$. At a concentration of $1 \mathrm{mg} / \mathrm{ml}$, we could not detect cells after SD and Lipobean ${ }^{\circledR}$ treatment, because they resulted in cell membrane lysis (data not shown). For the same reason, the cell membrane was disrupted, so protein was not detected in Western blot analysis when differentiated 3T3-L1 cells were treated with $1 \mathrm{mg} / \mathrm{ml}$ of SD or Lipobean ${ }^{\circledR}$ (Figure $4 \mathrm{C}$ ). However, PPC treatment showed clear caspase- 8 and PARP cleavage, indicating that PPC induced apoptosis of differentiated 3T3-L1 cells.

\section{Discussion}

In past years, nonsurgical lipolysis has increased [7], and is the most economical use of subcutaneous injections to reduce local fat via chemical lipolysis [8]. PPC injections using a variety of PPC formulations are popular as a treatment of local adiposities [24]. However, no product intended for lipodissolution has yet been approved by the Food and Drug Administration, Medicines and Healthcare Products Regulatory Agency (MHRA), because of lack of data concerning safety and efficacy [24].

A PPC formulation generally used clinically consists of PPC and SD [24]. It has been suggested that SD, the detergent in the PPC formulation, is the active lipodissolving substance, and not PPC [25]. The main side effects of injection of PPC formulations are relatively minor, and include swelling, bruising, and sensitivity to touch under the skin in areas with the lipodissolution treatments [26]. However, since injection of SD causes focal necrosis and inflammation in human lipomas [25], it is entirely conceivable that the aforementioned side effects of PPC formulations are due to SD, not to PPC itself. Presently, we confirmed that SD induces cell membrane lysis, resulting in necrosis. Interestingly, however, the results of the MTT assay clearly indicate that PPC alone without SD induced cell death of 3T3-L1 pre-adipocytes. The results also demonstrated that the effects of inducing 3T3-L1 cell death by PPC formulation did not depend only on SD. In addition, our flow cytometric experiments showed that Lipobean ${ }^{\circledR}$ treatment resulted in cell membrane lyses because of SD (data not shown). A large discrepancy in the extent of cell viability was presently evident between $0.5 \mathrm{mg} / \mathrm{ml}$ and $1 \mathrm{mg} / \mathrm{ml}$ Lipobean ${ }^{\circledR}$ (Figure 1C). These Lipobean ${ }^{\circledR}$ concentrations may be at the threshold for membrane stability.

In agreement with our study, PPC formulation and SD induce the lysis of various cell types including pre-adipocytes, normal human fibroblasts, endothelial cells, and skeletal muscle cells in a nonspecific manner [7]. These results are very important because the injection of PPC formulation may cause tissue necrosis. However, in our study, PPC alone did not induce cell death of CCD25Sk normal fibroblasts. It is very important that PPC reduced only adipocyte viability specifically, but did not decrease cell viability of other cell types such as fibroblasts. On the other hand, PPC formulation and SD induced cell death of both cell types. These results indicate that the SD constituent of PPC formulations initiates the cell lysis, leading to cell death. Clearly, more study is required to confirm this suggestion.

PPC induces apoptosis in cells such as colon cancer cells [27], vascular endothelial cells [28], and macrophages [29]. Phosphorylation of stress-activated protein kinase pathways [30] and cleavage of caspases are main pathways of apoptosis [31]. Especially, the death-receptor inducing activation of caspase- 8 and mitochondrial pathways is the key point of apoptotic pathways [32]. In the present study, PPC induced not only the activation of p38 and JNK, but also the cleavage of caspase-8, -9, -3, and PARP in 3T3-L1 pre-adipocytes (Figure 3). Specifically, PPC treatment unequivocably activated caspase-8 in both 3T3-L1 pre-adipocytes and differentiated 3T3-L1 cells (Figures 3B and 4C). The caspase-8 pathway is intimately involved in CD95-mediated apoptotic cell death $[33,34]$. These results indicate that PPCinduced apoptosis may be due to increased death receptor activations. This possibility should be further examined to elucidate PPC-induced apoptotic pathways.

Furthermore, the increase of sub- $G_{1}$ fraction is an indication of apoptosis that naturally occurs in cells [35], and the sub- $\mathrm{G}_{1}$ phase in the cell cycle is increased in apoptotic cell death [36]. Therefore, to characterize apoptotic cells upon treatment of PPC, SD, and PPC formulation, flow cytometric analysis was presently performed. Treatment with $0.1 \mathrm{mg} / \mathrm{ml}$ PPC treatment increased sub- $\mathrm{G}_{1}$ phase in 3T3-L1 adipocytes. These results favor the view that PPC induces apoptosis of 3T3-L1 cells.

\section{Conclusions}

In conclusion, it can be suggested that PPC alone has an apoptotic effect on 3T3-L1 adipocytes. Thus, PPC without SD should be used for the potential drug of treatment of local fat to avoid the main side effects of PPC formulation. For this purpose, a new drug delivery method will be needed for a PPC formulation without SD. Because PPC may form liposomal vesicles in aqueous solution, PPC liposomes could be adequate for a new drug delivery method.

\section{Abbreviations}

JNK: c-Jun N-terminal kinase; MAPK: mitogen-activated protein kinase; MDI: 3-isobutyl-1-methylxanthine: dexamethasone: insulin; PARP: poly(ADP-ribose) polymerase; PPC: phosphatidylcholine; SD: sodium deoxycholate.

\section{Acknowledgements}

This study was supported by AmiPharm Research Fund (Seoul, Korea). 


\section{Author details}

'Departments of Biochemistry, Chung-Ang University College of Medicine, 221 Heukseok-dong, Dongjak-gu, Seoul 156-756, Republic of Korea. ${ }^{2}$ Departments of Pharmacology, Chung-Ang University College of Medicine, 221 Heukseok-dong, Dongjak-gu, Seoul 156-756, Republic of Korea.

${ }^{3}$ Departments of Microbiology, Chung-Ang University College of Medicine, 221 Heukseok-dong, Dongjak-gu, Seoul 156-756, Republic of Korea.

\section{Authors' contributions}

HL participated in data acquisition, interpretation, and the writing of this manuscript. JHL, SYK, HYY, KJB, NSK, YY, and JHJ participated in the study design and data interpretation. DSK contributed to the experimental design, data interpretation, editing, and submission of this manuscript. All authors read and approved the final manuscript.

\section{Competing interests}

The authors declare that they have no competing interests.

Received: 1 September 2011 Accepted: 7 December 2011

Published: 7 December 2011

\section{References}

1. Pistor M: What is mesotherapy? Chir Dent Fr 1976, 46:59-60,

2. Young VL: Lipostabil: the effect of phosphatidylcholine on subcutaneous fat. Aesthet Surg J 2003, 23:413-417.

3. Rotunda AM, Kolodney MS: Mesotherapy and phosphatidylcholine injections: historical clarification and review. Dermatol Surg 2006, 32:465-480.

4. Ablon G, Rotunda AM: Treatment of lower eyelid fat pads using phosphatidylcholine: clinical trial and review. Dermatol Surg 2004, 30:422-427, discussion 428.

5. Rittes PG: The use of phosphatidylcholine for correction of localized fat deposits. Aesthetic Plast Surg 2003, 27:315-318.

6. Klein $S M$, Schreml S, Nerlich M, Prantl L: In vitro studies investigating the effect of subcutaneous phosphatidylcholine injections in the 3T3-L1 adipocyte model: lipolysis or lipid dissolution? Plast Reconstr Surg 2009, 124:419-427.

7. Gupta A, Lobocki C, Singh S, Robertson M, Akadiri OA, Malhotra G, Jackson IT: Actions and comparative efficacy of phosphatidylcholine formulation and isolated sodium deoxycholate for different cell types. Aesthetic Plast Surg 2009, 33:346-352.

8. Salti G, Ghersetich I, Tantussi F, Bovani B, Lotti T: Phosphatidylcholine and sodium deoxycholate in the treatment of localized fat: a double-blind, randomized study. Dermatol Surg 2008, 34:60-66, discussion 66

9. Moessinger C, Kuerschner L, Spandl J, Shevchenko A, Thiele C: Human lysophosphatidylcholine acyltransferases 1 and 2 are located in lipid droplets where they catalyze the formation of phosphatidylcholine. $J$ Biol Chem 2011, 286:21330-21339

10. Vance JE, Vance DE: Phospholipid biosynthesis in mammalian cells. Biochem Cell Biol 2004, 82:113-128.

11. Aleynik SI, Lieber CS: Polyenylphosphatidylcholine corrects the alcoholinduced hepatic oxidative stress by restoring s-adenosylmethionine. Alcohol Alcohol 2003, 38:208-212.

12. Harayama T, Shindou H, Shimizu T: Biosynthesis of phosphatidylcholine by human lysophosphatidylcholine acyltransferase 1.J Lipid Res 2009, 50:1824-1831

13. Sakakima Y, Hayakawa A, Nakao A: Phosphatidylcholine induces growth inhibition of hepatic cancer by apoptosis via death ligands. Hepatogastroenterology 2009, 56:481-484.

14. Kopera D, Binder B, Toplak H: Intralesional lipolysis with phosphatidylcholine for the treatment of lipomas: pilot study. Arch Dermatol 2006, 142:395-396.

15. Weiss R, Dziura J, Burgert TS, Tamborlane WW, Taksali SE, Yeckel CW, Allen K, Lopes M, Savoye M, Morrison J, Sherwin RS, Caprio S: Obesity and the metabolic syndrome in children and adolescents. N Engl J Med 2004, 350:2362-2374

16. Sorisky A, Magun R, Gagnon AM: Adipose cell apoptosis: death in the energy depot. Int J Obes Relat Metab Disord 2000, 24(Suppl 4):S3-7.

17. Levine JA, Jensen MD, Eberhardt NL, O'Brien T: Adipocyte macrophage colony-stimulating factor is a mediator of adipose tissue growth. $J$ Clin Invest 1998, 101:1557-1564.
18. Xiao Y, Yuan T, Yao W, Liao K: 3T3-L1 adipocyte apoptosis induced by thiazolidinediones is peroxisome proliferator-activated receptor-gammadependent and mediated by the caspase-3-dependent apoptotic pathway. FEBS J 2010, 277:687-696.

19. Hengartner MO: The biochemistry of apoptosis. Nature 2000, 407:770-776.

20. Shah GM, Shah RG, Poirier GG: Different cleavage pattern for poly(ADPribose) polymerase during necrosis and apoptosis in $\mathrm{HL}-60$ cells. Biochem Biophys Res Commun 1996, 229:838-844.

21. Casiano CA, Ochs RL, Tan EM: Distinct cleavage products of nuclear proteins in apoptosis and necrosis revealed by autoantibody probes. Cell Death Differ 1998, 5:183-190.

22. Wu BT, Hung PF, Chen HC, Huang RN, Chang HH, Kao YH: The apoptotic effect of green tea (-)-epigallocatechin gallate on 3T3-L1 preadipocytes depends on the Cdk2 pathway. J Agric Food Chem 2005, 53:5695-5701.

23. Rotunda AM, Suzuki H, Moy RL, Kolodney MS: Detergent effects of sodium deoxycholate are a major feature of an injectable phosphatidylcholine formulation used for localized fat dissolution. Dermatol Surg 2004 30:1001-1008.

24. Duncan DI, Palmer M: Fat reduction using phosphatidylcholine/sodium deoxycholate injections: standard of practice. Aesthetic Plast Surg 2008, 32:858-872.

25. Rotunda AM, Ablon G, Kolodney MS: Lipomas treated with subcutaneous deoxycholate injections. J Am Acad Dermatol 2005, 53:973-978.

26. Hasengschwandtner F: Phosphatidylcholine treatment to induce lipolysis. J Cosmet Dermatol 2005, 4:308-313.

27. Fukunaga K, Hossain Z, Takahashi K: Marine phosphatidylcholine suppresses 1,2-dimethylhydrazine-induced colon carcinogenesis in rats by inducing apoptosis. Nutr Res 2008, 28:635-640.

28. Cheng Y, Zhao Q, Liu X, Araki S, Zhang S, Miao J: Phosphatidylcholine-specific phospholipase C, p53 and ROS in the association of apoptosis and senescence in vascular endothelial cells. FEBS Lett 2006, 580:4911-4915.

29. Baez JM, Tabas I, Cohen DE: Decreased lipid efflux and increased susceptibility to cholesterol-induced apoptosis in macrophages lacking phosphatidylcholine transfer protein. Biochem J 2005, 388:57-63.

30. Wagner EF, Nebreda AR: Signal integration by JNK and p38 MAPK pathways in cancer development. Nat Rev Cancer 2009, 9:537-549.

31. Fulda S: Caspase-8 in cancer biology and therapy. Cancer Lett 2009, 281:128-133.

32. Jeong YM, Li H, Kim SY, Park WJ, Yun HY, Baek KJ, Kwon NS, Jeong JH Myung SC, Kim DS: Photo-activated 5-hydroxyindole-3-acetic acid induces apoptosis of prostate and bladder cancer cells. J Photochem Photobiol B 2011, 103:50-56.

33. Denning TL, Takaishi H, Crowe SE, Boldogh I, Jevnikar A, Ernst PB: Oxidative stress induces the expression of Fas and Fas ligand and apoptosis in murine intestinal epithelial cells. Free Radic Biol Med 2002, 33:1641-1650.

34. Facchinetti F, Furegato $S$, Terrazzino S, Leon $\mathrm{A}: \mathrm{H}(2) \mathrm{O}(2)$ induces upregulation of Fas and Fas ligand expression in NGF-differentiated PC12 cells: modulation by CAMP. J Neurosci Res 2002, 69:178-188.

35. Watanapokasin R, Jarinthanan F, Nakamura Y, Sawasjirakij N, Jaratrungtawee A, Suksamrarn S: Effects of alpha-mangostin on apoptosis induction of human colon cancer. World I Gastroenterol 2011, 17:2086-2095.

36. Kim ND, Im E, Yoo YH, Choi YH: Modulation of the cell cycle and induction of apoptosis in human cancer cells by synthetic bile acids. Curr Cancer Drug Targets 2006, 6:681-689.

doi:10.1186/1423-0127-18-91

Cite this article as: Li et al:: Phosphatidylcholine induces apoptosis of 3T3-L1 adipocytes. Journal of Biomedical Science 2011 18:91. 